\title{
Determination of Some Quality and Safety Parameters for Black Raisin Juice
}

\author{
Yakup Aslan (Corresponding author) \\ Department of Food Engineering, Faculty of Engineering, Siirt University \\ Postal Code: 56100, Siirt, Turkey \\ E-mail: dr_yakup@siirt.edu.tr \\ Hawsar S. Hussein \\ Department of Food Engineering, Faculty of Engineering, Siirt University \\ Postal Code: 56100, Siirt, Turkey \\ E-mail: hawsar9@gmail.com \\ Seerwan A. Abdullah \\ Department of Food Technology, University of Salahaddin \\ Postal Code: 44001, Arbil, Kurdistan, Iraq \\ E-mail: serwan.abdullah@su.edu.krd \\ Isa Cavidoglu \\ Department of Food Engineering, Faculty of Engineering, Van Yuzuncu Yil University \\ Postal Code: 65080, Van, Turkey \\ E-mail: isacavidoglu@yyu.edu.tr
}

The research is financed by Scientific Research Projects Coordinatorship (BAP) of Siirt University with code 2017-SIÜFEB-09

\begin{abstract}
The aim of the present study was to determine the safety and the quality parameters of raisin juice, such as total soluble solids (TSS), pH, titratable acidity (TTA), kinds and quantity of sugars, phenolic acid compounds, polyphenoloxidase (PPO) enzyme activity, water activity and total microbial counts. The total soluble solids and $\mathrm{pH}$ values were significantly decreased after two weeks of storage, while the titratable acidity in most samples were slightly changed. Glucose, fructose and sucrose as well as three kinds of phenolic acids such as gallic, chlorogenic and vanilic acids were determined in all samples. Total microbial contents of the freshly prepared raisin juice and of the raisin juice stored for one and two weeks did not significantly changed. The water activity was slightly decreased, while the polyphenoloxidase activity was significantly decreased, after storage for two weeks. Consequently, it can be said that the freshly prepared raisin juice and the raisin juice stored for one week have superior sensorial properties than the raisin juice stored for two weeks.
\end{abstract}

Keywords: Quality and safety, black raisin juice, phenolic acid compounds, polyphenoloxidase

\section{Introduction}

Grape is a non-climacteric fruiting that grows on the perennial and deciduous woody vines of the genus Vitis that are mainly found in the moderate zones of the northern hemisphere and plurality divided between America and Asia (Mullins et al., 1992).

Drying is one of the oldest methods used to preserve fruits by reducing moisture contents and reaction rate to increase the shelf life of products. The moisture content is changed with drying period time of samples in open sun drying. Initial moisture content in grape varied between $78 \%$ and $80 \%(\mathrm{w} / \mathrm{w})$, was reduced to the final water content of $22 \%(\mathrm{w} / \mathrm{w})$. Three methods are used for dehydration of grapes; the first one is a considered, sun or natural dryers, which it is low-cost process also the quality of natural dried fruits is affected, and there is a little likeness to the fresh fruit. The second one is direct solar dryers. In this dryer, the material to be dried is placed in poly net-shad-with or without transparent covers or side panels. The third one is indirect solar dryer, which is the new and more effective technique of product 
drying. The drinking of fruit juices could have both positive and negative impact on the health of consumers. Consumer demands safety and good processed foods with higher-quality properties have encouraged better food production (Riahi and Ramaswamy, 2004). Freshly expressed grape juice consists of 70 to $80 \%$ moisture and numerous dissolved solids. These soluble solids include many organic and inorganic compounds.

Natural juice is the non-fermented or fermented product obtained from fruit through the physical methods to maintain the basic structure and the quality. The juice can evoke the use of carbon dioxide (Iraqi standard, 1988). Shi et al. (2003) were investigated universal phenolic acids in grapes contain benzoic acids (galic acid, vanilinic acid, protocatechuic acid, and p-hydroxybenzoic acids) and cinnamic acids (chlorogenic acid, caffeic acid coumaric acid, ferulic acid, and neochlorogenic acid). Phytochemicals such as phenolic compounds, carotenoids, flavonoids, and vitamins in fruit juices play an important role in disease protection (Gardner et al., 2000). The consumption of polyphenol-load juice improves antioxidant status. (Bub et al., 2003).

Raisin juice consumed fresh fruits and especially is valuable for its tangy taste. It has a low shelf-life during seven days storage in refrigerator; this is because of (1) natural contamination of raisin juice by bacteria and molds, (2) enzymatic activities (Polyphenol oxidase and peroxidase) and these lead to changes in taste and flavor during storage. Storage of raisin juices at refrigerator is not always best method for the prevention of desirable quality of some fruits. Water used for juice preparation can be the main source of microbial contamination. The polyphenol oxidase (PPO) enzyme is highly heat sensitive and its activity reduced during the dehydration process. The residues of this enzyme interfere with the discoloration of the raisins during storage. However, juice properties such as appearance, taste, and odor are made undesirably changed via effects of enzymes such as PPO enzyme, peroxidase, and pectin methylesterase (Awuah, 2007). For these case, there are big losses in their market value demandand product quality (Gauillard and Richard-Forget 1997).

No such research has been carried out in this field, related to Arbil and Sulaymaniyah grapes, whichare most widely used in Iraq. In order to develop awareness people about raisin juices, this studyefforts to measure phenolic compounds, ascorbic acid, activity of polyphenol oxidase enzymeand total microbial counts as the main parameters of quality and safety of raisin juice which ismechanically extracted.

The objectives of this study were: Characterizationof local black raisin (Vitis vinifera ) juice samples as quality and safety parameters: (1) determination of some physical and chemical properties including $\mathrm{pH}$, brix values, and titratable acidity, (2) quantitative determination of phenolic acids using highperformance liquid chromatography (HPLC) in flesh, seed and juice of local raisins. (3) quantitative determination the activity of PPO in raisin and raisin juices,(4)microbial analysis during normal storage of samples and (5) determination of sensory quality andthe acceptability of raisin juice drinks during storage.

\section{Experimentals}

\subsection{Materials}

Hand-held Refractometer (RHB-50ATC/0-50\% Brix) was purchased from Grandidex company (China ). Benchtop pH Meter BP3001 was purchased from Trans Instruments (S) Pte Ltd. (Jalan Kilang Barat, Singapur). UltiMate 3000 HPLC systems and UV-Visible Evolution 200 were purchased from Thermo Fisher Scientific (Waltham, MA USA). 4-Hydroxybenzoic acid, vanillic acids, and galic acids, D - (+) glucose, acetoneitrile, methanol, phosphoric acid, formic acid, potassium phosphate monobasic, caffeic acid, chlororogenic acids, sucrose, maltose monohydrate, D-fructose, ascorbic acid solution, polyphenol oxidase enzyme solution, ethylenediaminetetraacetic acid (EDTA) solution, and potassium dihydrogen phosphate were purchased from Sigma-Aldrich (Darmstadt, Germany). Phenolphthalein and sodium hydroxide solution were purchased from Merck (Darmstadt, Germany). CHROMAFIL XTRA PVDF20/25 filter was purchased from Macherey-Nagel GmbH \& Co. KG (Duren, Germany)

\subsection{Methods}

\subsubsection{Collecting the black raisin samples}

Locally black raisin juice made from seed Vitus vinifera grapes, four samples of black raisins (black dried grapes) (Tre-rash varieties sample A, B) from Sulaimaniya and (Rashmiree samples C, D ) from Arbil were collected from different local market. Two natural black raisin juice was extracted (A and C) 
and another two samples of raisin juice (B and D) were purchased from local market and then all samples were used for experiments in order to investigate the quality and safety of locally raisin juices in four bottles were stored at $+4^{\circ} \mathrm{C}$ for two weeks.

\subsubsection{Preparation of freshly squeezed raisin juice samples for analysis}

The samples were prepared for analysis according to Abdullah's method (2012). $1 \mathrm{~kg}$ of raisins was washed in tap water, and soaked in water for some hour, and mixed with $2.5 \mathrm{~L}$ of water and were grounded before being squeezed with the cheese-cloth. The prepared raisin juice samples $\mathrm{A}$ and $\mathrm{C}$ were stored at $+4^{\circ} \mathrm{C}$ in the refrigerator for two weeks until used for analysis.

\subsubsection{Determinatin of moisture content}

$5 \mathrm{~g}$ raisins from each sample (A to D) were dried in an oven at $70{ }^{\circ} \mathrm{C}$ for six hours, and then after cooling in a desiccator, the samples were weighed to a constant value. Three replicates of weighing was conducted for each sample. The Equation 1 was used to calculate the moisture content of samples (Anonym, 1992).

$M_{n}=\left[\left(W_{w}-W_{d}\right) / W_{w}\right] \times 100$

in where:

$\mathrm{M}_{\mathrm{n}}=$ moisture content (\%) of material

$\mathrm{W}_{\mathrm{w}}=$ wet weight of the sample, and

$\mathrm{W}_{\mathrm{d}}=$ weight of the sample after drying.

\subsubsection{Determinatin of $\mathrm{pH}$ values of sample}

The $\mathrm{pH}$ values of raisin juices were determined using $\mathrm{pH}$ meter (Benchtop $\mathrm{pH}$ Meter BP3001), at room temperature. Before measurements, $\mathrm{pH}$ meter was calibrated using calibration buffers ( $\mathrm{pH} \mathrm{4,7}$ and 10). Raisin juices were tested three times ( 0,7 and 14 days), in triplicate during storage in a refrigerator at +4 ${ }^{\circ} \mathrm{C}$.

\subsubsection{Determination of total soluble solids (Brix value)}

Total soluble solid (TSS) contents of raisin juice samples were determined as Brix value using a refractometer. To determine the Brix levels of the raisin juice samples, a few drops of the samples were placed on the prism and closed before reading the refractometer scale, then the values at $20^{\circ} \mathrm{C}$ were recorded three times for each sample. TSS values of raisin juices were determined three times $(0,7$ and 14 days) during storage in a refrigerator at $+4{ }^{\circ} \mathrm{C}$.

\subsubsection{Determination of total titratable acidity}

$5 \mathrm{~mL}$ of raisin juices were taken for each sample and distilled water was added up to $100 \mathrm{ml}$ in a $250 \mathrm{~mL}$ conical flask, then titrated against $0.067 \mathrm{~N}$ sodium hydroxide solution using phenolphthalein as indicator. Three replicates for each sample were conducted. The total titratable acidity (TTA) was calculated as $\mathrm{g} / \mathrm{L}$ tartaric acid according to Equation 2 (Xu et al., 2012) Raisin juices was tested three times (0, 7 and 14 days) during storage in a refrigerator at $+4{ }^{\circ} \mathrm{C}$.

$\operatorname{TTA}(\mathrm{g} / \mathrm{L})$ Tartaric Acid $=\frac{\mathrm{NaOH}(\mathrm{mL}) \times 0.1 \mathrm{~N} \mathrm{NaOH} \times 0.075 * \times 1000}{\text { Sample volume }(\mathrm{mL})}$

$*=$ equivalent weight of tartaric acid

\subsubsection{Determinations of kinds and quantity of sugar contents}

Fructose, glucose, sucrose and maltose contents were determined using HPLC according to Turkish Standard Method (TS, 2008). $7.5 \mathrm{ml}$ of raisin juice and $2.5 \mathrm{ml}$ of methanol were mixed in a flask and shaked. After the mixture was filtered into HPLC vials using filters (pore size $0.25 \mu \mathrm{m}$ ) before HPLC analysis. All samples were analyzed three times ( 0,7 and 14 days) during storage at $+4 \mathrm{oC}$. 


\subsubsection{Determination of phenolic compounds by using HPLC}

Determination of quality and quantity of phenolic acids in seeds and flesh of raisins individually as well as in fresh raisin juice, after one week and two weeks from a squeezed raisin juice and stored at $+4{ }^{\circ} \mathrm{C}$ in the refrigerator until analysis have been done by using HPLC.

\subsubsection{Sample preparation}

A-Seed and flesh. $2 \mathrm{~g}$ grounded seed and flesh were taken into the volumetric flasks. $10 \mathrm{~mL}$ of distilled water: methanol mixtures (95:5) were added and then were shaked in water bath at $200 \mathrm{rpm}$ and $50{ }^{\circ} \mathrm{C}$ for one hour, later were centrifuged at $5000 \mathrm{rpm}$ for $5 \mathrm{~min}$. The extracts were filtered into vials using filters (pore sizes were $0.22 \mu \mathrm{m}$ ) and used for HPLC analysis.

B- Raisin juices. $0.5 \mathrm{~mL}$ methanol samples were added into volumetric flasks containing $9.5 \mathrm{ml}$ juices and after then this mixtures were filtered using vials with $0.22 \mu \mathrm{m}$ filter. The filtrates were used for the analysis with HPLC

Analytical column: Thermo $250 \mathrm{~mm} \times 4,6 \mathrm{~mm}$ x 5 um ID, hypersil gold

Flow rate: $0.75 \mathrm{~mL} / \mathrm{min}$

Solvent A: Water: Formic Acid (98: 2) Solvent B: water: Acetonitrile: Formic Acid (78:20:2)

Column temperature: $28^{\circ} \mathrm{C} \pm 1{ }^{\circ} \mathrm{C}$

Injection volume: $20 \mu \mathrm{L}$

Standard stocks:

Gallic acid: 30 ppm (280 nm)

Colorogenic acid: 60 ppm $(280 \mathrm{~nm})$

Caffeic acid: 20 ppm (320 nm)

4-Hydroxy aenzoic Acid: 40 ppm (280 nm)

Vanilic acid: 20 ppm (280 nm)

$1 \mathrm{~min} 0.75 \mathrm{~mL} / \mathrm{min} \mathrm{A} \% 75 \mathrm{~B} \% 25$.

$5 \mathrm{~min} 0.75 \mathrm{~mL} / \mathrm{min} \mathrm{A} \% 50 \mathrm{~B} \% 50$

$10 \min 0.75 \mathrm{~mL} / \mathrm{min} \mathrm{A} \% 25 \mathrm{~B} \% 75$

$12 \mathrm{~min} 0.75 \mathrm{~mL} / \mathrm{min} \mathrm{A} \% 25 \mathrm{~B} \% 75$

$15 \mathrm{~min} 0.75 \mathrm{~mL} / \mathrm{min} \mathrm{A} \% 0 \mathrm{~B} \% 100$ (Slightly modified)

The system components were SPD-M20A diode array detector, SIL-20A HT autosampler, CTO-20A column oven, and DGU-20A5 degas units. Chromatography was performed at wavelengths of $280 \mathrm{~nm}$ and $320 \mathrm{~nm}$ (Table 1) and a C18 column with $250 \times 4.6 \times 5 \mathrm{~mm}$ dimensions was used. Mobile phase A; water/formic acid (98:2), mobile phase B water/acetonitrile/formic acid (78:20:2) and the mobile phase $\mathrm{C}$ was regulated as $100 \%$ methanol. Injection volume $20 \mu \mathrm{L}$, the flow rate was $0.75 \mathrm{~mL} / \mathrm{min}$ and the temperature was set at $28{ }^{\circ} \mathrm{C}$. As the flow gradients of mobile phases were given above. As a flow program External standards were used in order to the identification of the different phenolic compounds. For example, phenolic acids standards were used at least with 5 different concentrations. All calibration coefficients $\left(\mathrm{R}^{2}\right)$ of standard plots were greater than 0.990 .

Table 1. Analysis parameters of phenolic acids

\begin{tabular}{lccccccc}
\hline Sample Name & UV (nm) & RT (min) & $\mathbf{1 0 0 \%}$ & $\mathbf{8 0 \%}$ & $\mathbf{4 0 \%}$ & $\mathbf{2 0 \%}$ & $\mathbf{1 0 \%}$ \\
\hline Gallic acid & 280 & 4.187 & $30 \mathrm{ppm}$ & $24 \mathrm{ppm}$ & $12 \mathrm{ppm}$ & $6 \mathrm{ppm}$ & $3 \mathrm{ppm}$ \\
Cholorogenic acid & 280 & 4.877 & $60 \mathrm{ppm}$ & $48 \mathrm{ppm}$ & $24 \mathrm{ppm}$ & $12 \mathrm{ppm}$ & $6 \mathrm{ppm}$ \\
Caffeic acid & 320 & 6.797 & $20 \mathrm{ppm}$ & $16 \mathrm{ppm}$ & $8 \mathrm{ppm}$ & $4 \mathrm{ppm}$ & $2 \mathrm{ppm}$ \\
4-hydroxy benzoic acid & 280 & 6.763 & $40 \mathrm{ppm}$ & $32 \mathrm{ppm}$ & $16 \mathrm{ppm}$ & $8 \mathrm{ppm}$ & $4 \mathrm{ppm}$ \\
Vanilic Acid & 280 & 9.793 & $20 \mathrm{ppm}$ & $16 \mathrm{ppm}$ & $8 \mathrm{ppm}$ & $4 \mathrm{ppm}$ & $2 \mathrm{ppm}$ \\
\hline
\end{tabular}

61 | P a g e 


\subsubsection{Enzymatic assay of Poly Phenol Oxidase}

Method: Continuous Spectrophotometric activity determination.

\section{Reagents:}

1. $50 \mathrm{mM}$ potassium phosphate buffer, $\mathrm{pH} 6.5$

2. $5 \mathrm{mM} \mathrm{L-3,4-Dihydroxyphenylalanine} \mathrm{solution.}$

3. $2.1 \mathrm{mM}$ L-ascorbic acid solution.

4. $0.065 \mathrm{mM}$ Ethylenediaminetetraacetic acid solution (EDTA).

5. Poly Phenol Oxidase (PPO) enzyme solution (containing $500-1000$ units $/ \mathrm{mL}$ of PPO in cold reagent A.)

Procedure: The following reagents were pipetted (in milliliters) into suitable quartz cuvettes (Table 2). They were mixed by inversion and equilibrate to $25^{\circ} \mathrm{C}$. Monitor the $\mathrm{A}_{265} \mathrm{~nm}$ until constant, using a suitable thermostatted spectrophotometer. Then added reagent E. They immediately mixed by inversion and record the decrease in $\mathrm{A}_{265} \mathrm{~nm}$ for approximately 5 minutes.

The $\mathrm{A}_{265 \mathrm{~nm}} /$ minute is obtained using the maximum linear rate for both the test and blank.

Calculation: Enzyme unit was calculated using Equation 3.

Units $/ m g$ enzyme $=\frac{\Delta A_{265 \mathrm{~nm}} / \mathrm{min} \text { Test }-\Delta A_{265 \mathrm{~nm}} / \mathrm{min} \text { Blank }}{(0.001)(\mathrm{mg} \text { Enzyme } / \mathrm{RM})}$

$0.001=$ the change in $\mathrm{A}_{265} \mathrm{~nm} /$ minute per unit $\mathrm{PPO}$ at $\mathrm{pH} 6.5$ at $25^{\circ} \mathrm{C}$ in a $3 \mathrm{~mL}$ reaction mixture.

$\mathrm{RM}=$ Reaction Mixture $(3 \mathrm{~mL})$

Unit definition: One unit was enzyme amount that caused the change in $\mathrm{A}_{265 \mathrm{~nm}}$ of 0.001 per minute in a $3 \mathrm{~mL}$ reaction mix containing L-3,4-dihydroxyphenylalanine and L-ascorbic acid at $\mathrm{pH} 6.5$ at $25^{\circ} \mathrm{C}$.

Final assay concentrations: In $3 \mathrm{~mL}$ reaction mixture, the final concentrations: potassium phosphate buffer was $50 \mathrm{mM}$, L-ascorbic acide was $0.17 \mathrm{mM}$ and PPO was 50-100 units (Dawson et al., 1955; Marumo et al., 1986).

\subsubsection{Water activity}

Measurement of water activity $\left(\mathrm{a}_{\mathrm{w}}\right)$ was carried out using a water activity meter at $25^{\circ} \mathrm{C}$. The raisin samples were first sliced into thin pieces and placed in a small chamber and a few drops of the raisin juices were added into the reading cell. All samples were tested 3 times (fresh, after one week and two weeks) during storage in a refrigerator at $+4{ }^{\circ} \mathrm{C}$. The water in the chamber air was measured after reaching equilibrium conditions and the result at $25^{\circ} \mathrm{C}$ were recorded for each samples (steady state) (Aktas and Polat, 2007).

\subsubsection{Total bacterial counts}

Total bacterial counts were determined on 0,7 and 14. days of storage in a refrigerator at $+4^{\circ} \mathrm{C} .10 \mathrm{~mL}$ of the samples were diluted with $90 \mathrm{~mL}$ of sterile distilled water and mixed well to obtain 10-1 dilution. Serial dilutions 8-10 were prepared and spread plate technique was used on appropriate selective

Table 2. The amounts of reagents and blank

\begin{tabular}{lcc}
\hline Reagent & Test & Blank \\
\hline Reagent A (Buffer) & 2.60 & 2.80 \\
Reagent B (L-DOPA) & 0.10 & 0.10 \\
Reagent C (Ascorbic Acid) & 0.10 & 0.00 \\
Reagent D (EDTA) & 0.10 & 0.10 \\
Reagent E (Enzyme solution ) & 0.10 & 0.00 \\
\hline
\end{tabular}


media. Duplicate nutrient agar plates were used for each sample and incubated at $37 \pm 1^{\circ} \mathrm{C}$ for 48 hours. Plates containing 30-300 CFU/mL were selected for counting 3 times during storage in a refrigerator at $+4^{\circ} \mathrm{C}$ (Braide et al., 2012).

Number of colonies on plate $\mathrm{x}$ Reciprocal of dilution of samples $=$ Number of bacteria $/ \mathrm{mL}$

\subsubsection{Sensorial evaluation}

Sensorial evaluation of raisin juice is very important and gives a reliable opinion to appear the acceptability of new products. Samples were presented to at least ten panelists inside a plastic bottle. Appearance, aroma, taste, sweetness, and texture/mouth-feel were evaluated by the panelists on 0,7 , and 14 days of storage in terms of consumer acceptability. Panelists scored the samples using a five-point hedonic scale where a score of 1 dislike a lot and a score of 5 like a lot (Watts, 1989).

\subsubsection{Statistical analysis}

The PROC GLM (General Linear Model) procedure (SAS, 1999) was used to analyze the data in this study. Moreover, the Duncan multiple range tests used to a comparison between means for all traits under ( $\geq 0.05)$ level.

\section{Results and Discussions}

\subsection{Determination of moisture content in raisins}

Determining the moisture content of raisin plays an important role in estimating the shelf life consumables of grape berries. The grape properties directly affect raisin quality. Raisin is not considered as the agricultural perishable products which can be hardly deteriorated by microorganism because of its low content of moisture and water (Christensen, 1995). The obtained data showed that the highest moisture content (16.5\%) determined in sample B whereas sample $\mathrm{C}$ showed the lowest moisture content (14.9\%) (Fig. 1). Moreover, no significant differences observed between moisture content in all samples, except sample $\mathrm{C}$ which was significantly different from other samples. This is compatible with who reported the range of moisture content from 11-18\% (Christensen, 1995).

\subsection{Determination of $\mathrm{pH}$ values}

One of the crucial quality properties that illuminate the stability of bioactive compounds in fruit juice is $\mathrm{pH}$. Compounds such as organic acids are responsible for providing low $\mathrm{pH}$ in fruit juice. The $\mathrm{pH}$ can either rise or fall. (Tasnim et al. 2010). Fig. 2 showed that, fresh raisin juice sample A had the highest value of $\mathrm{pH}$ (4.23) and sample $\mathrm{D}$ had lowest value $\mathrm{pH}(2.96)$ in raisin juice sample refrigerated at the end of period (14 days), as well as the maximum differences between the fresh sample and last day of refrigerated sample was (-1.10) in sample D. At the same time, the influence of storage time had dramatic effects on the $\mathrm{pH}$ value in all samples; there was a significant decrease in $\mathrm{pH}$ value after 1 and 2 weeks. Boulton (1980) reported that the precipitation of potassium bitartrate either during fermentation or stabilization will cause fall of $\mathrm{pH}$. This result agrees with the results obtained in study of Mehmood et al (2008) related to the study of the effect of pasteurization and chemical preservatives on the quality and shelf stability of apple juice stored at ambient temperature for three months. However, similar results were found by Wisal et al (2013). The reason of decrease in the $\mathrm{pH}$ value during storage, it is possible to have biochemical reaction taking place during storage periods together with microbial action in the juices (Ibrahim, 2016). Otherwise, these results are a reverse portion of the results obtained by Mgaya-Kilima et al (2014), and Islam et al (2015).

\subsection{Determination of TSS}

TSS values of raisin juice stored under different storage period were given in Fig. 3. The total soluble solid values were ranged from $18.06 \%$ to $20.33 \%$ in fresh raisin juice A and B, respectively. However, the maximum value reduction of TSS was reached, while the lowest reduction was reached in samples after two weeks of storage. Moreover, in refrigeration condition, the TSS in all samples was decreased significantly after 2 weeks, but there was no significant difference between most of the samples after 1 week. This finding is consistent with the study of Wisal, et al (2013). They reported that approximately 0.5 Brix of TSS decreased in strawberry juice after being refrigerated for 20 days. Arin and Akdemir (2004) found the same results. TSS decrease at the end of the storage period (2 months). Bull et al. (2004) also investigated that the TSS by Brix of thermally processed Valencia and Navel orange juice. 


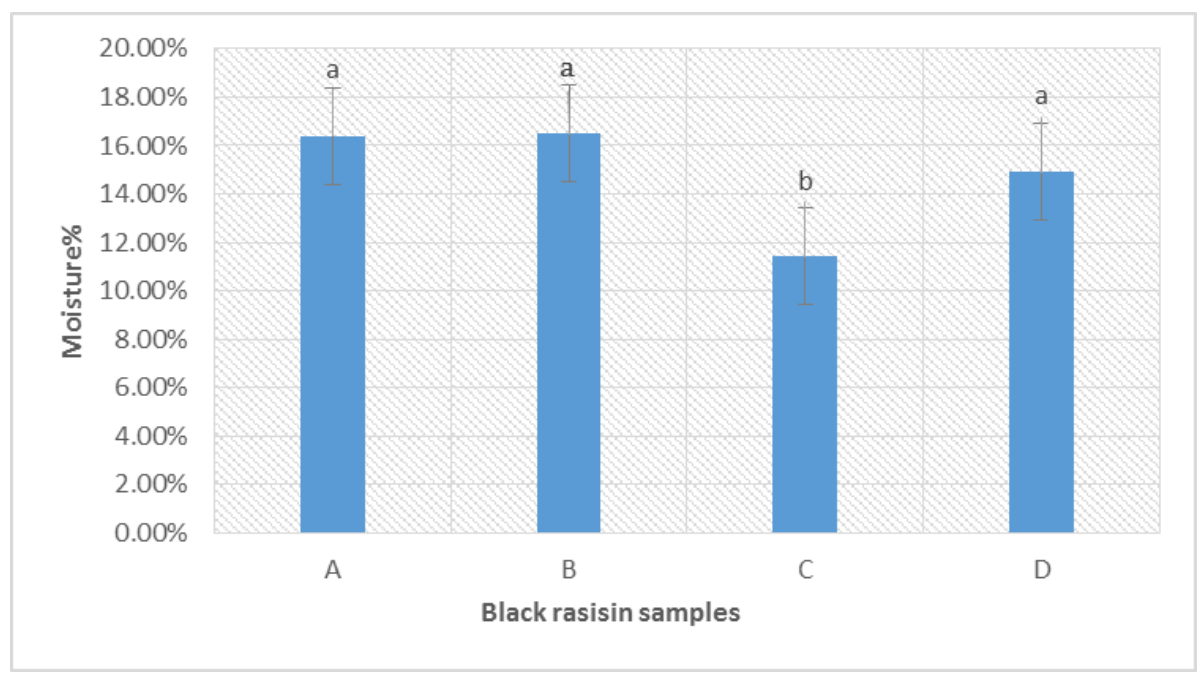

Fig 1. Moisture contents of raisin samples (A-D)

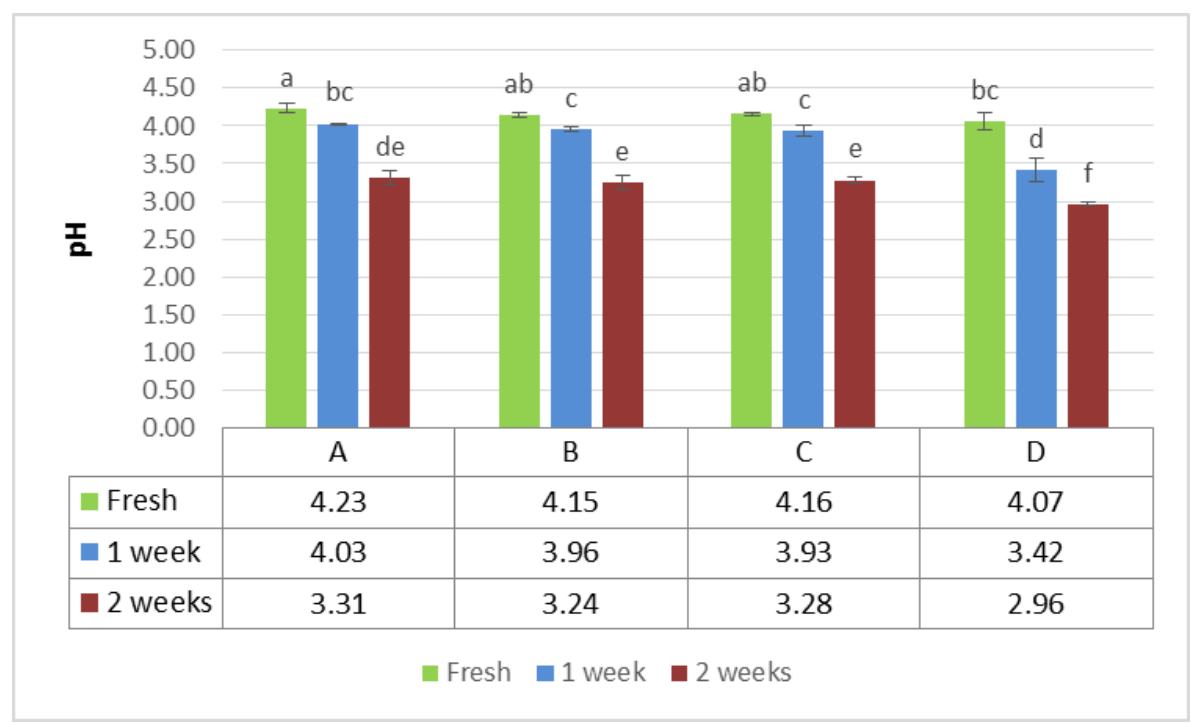

Fig 2. $\mathrm{pH}$ values of raisin juices (Samples A-D)

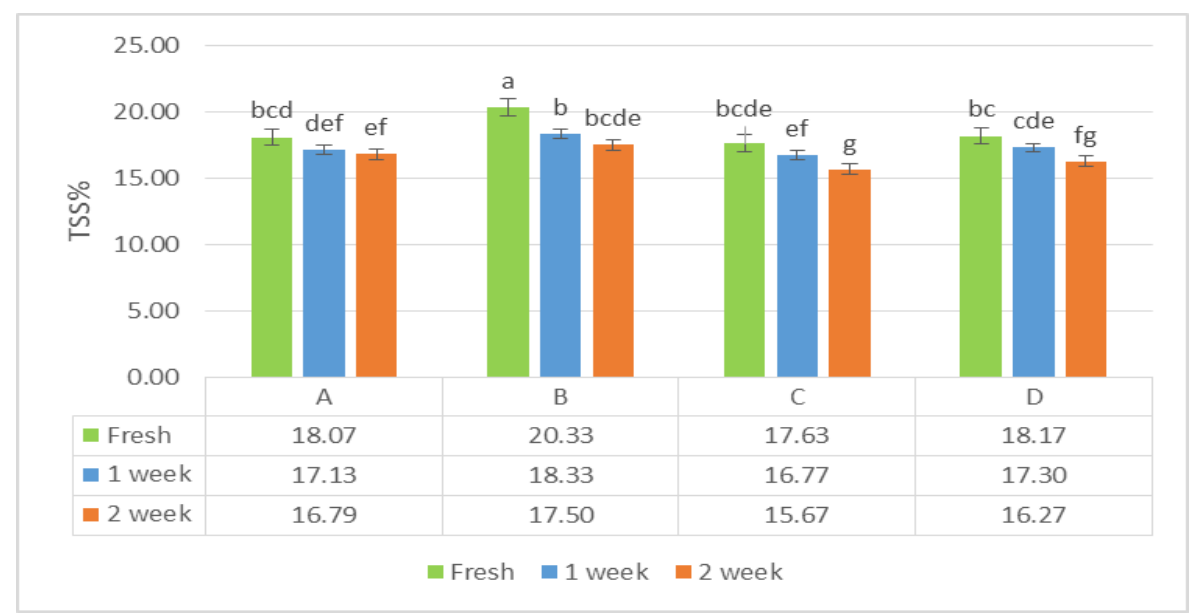

Fig 3. Total Soluble Solids ( ${ }^{\circ}$ Brix) of raisin juices 
TSS was not significantly changed during storage time in a refrigerator at $+4{ }^{\circ} \mathrm{C}$. On the other hand, this is a contrast with the observation by Mgaya-Kilima (2014) and Bhardwaj and Pandey (2011). Retention or a slight increase in the TSS of the roselle-fruit blends observed during 6 months at both storage temperatures $+4{ }^{\circ} \mathrm{C}$ and $28{ }^{\circ} \mathrm{C}$. Increase in total soluble solids may be due to break down of polysaccharides into monosaccharide and oligosaccharides that decreased possibly due to fermentation of these sugars into ethyl alcohol, carbon dioxide, and water.

\subsection{Determination of TTA}

Tartaric acid is most important acidic component in grape or raisin juice, and important standard for grape juice (Kanellis and Roubelakis, 1993). The main organic acid extracts in grapes are tartaric, malic, also little quantity of citric and succinic acid (Kliewer, 1966).The other acids in raisins obtained from different grape varieties return to tartaric, malic, citric, succinic acids during storage. Statistical analysis showed that the storage does not influence the titratable acidity in most samples. The formation of lactic acid, either during the alcoholic fermentation or the malo-lactic fermentation leads to lowering of both the total acidity and the titratable acidity (Boulton 1980). The same author reported that the precipitation of potassium bitartrate either during fermentation or stabilization will reduce both the total acidity and titratable acidity. As shown in Fig. 4, there are a significant difference between most of the fresh samples. The TTA in fresh samples B and D, were determined to be $3.01 \mathrm{~g} / \mathrm{L}$ and $8.14 \mathrm{~g} / \mathrm{L}$, respectively. The difference in TTA between the grape cultivars was expected, this can be due to some factors such as climate, variety, genetic and cultural practice (Dharmadhikari, 2010). High TTA can be an indication of the presence of tartaric acid (Kodur, 2011). As seen in the figure, D sample stored for two weeks showed the most TTA value $(9.57 \mathrm{~g} / \mathrm{L})$ while fresh B sample had showed the lowest TTA value $(3.01 \mathrm{~g} / \mathrm{L})$. According to Fig. 5, the TTA values of all samples had increased linearly with decreasing $\mathrm{pH}$ values.

\subsection{Qualitative and quantitative determinations of sugar contents}

One of the most crucial components of fruit products, essential for and also act as a natural food for prolonging of shelf life are sugars (Bhardwaj and Pandey 2011). The sugar content in grape is essential to produce raisins or table grape with an acceptable quality. It has been stated that the initial sugar content before drying should be more than $22^{\circ}$ Brix (Amerine, 1981). The raisin juice has a sweet taste; consequently, the major parameters for evaluating the quality of raisin juice are the concentration of sugars and $\mathrm{pH}$ acidity. Basically, with trace content of sucrose, glucose, and fructose which are present in grape or raisin juice, as well as there were considered the most soluble in water because there are belonged to reducing sugar as a monosaccharide. More significantly the hexose sugars in raisin juice are converted into alcohol through anaerobic fermentation conducted by yeasts.

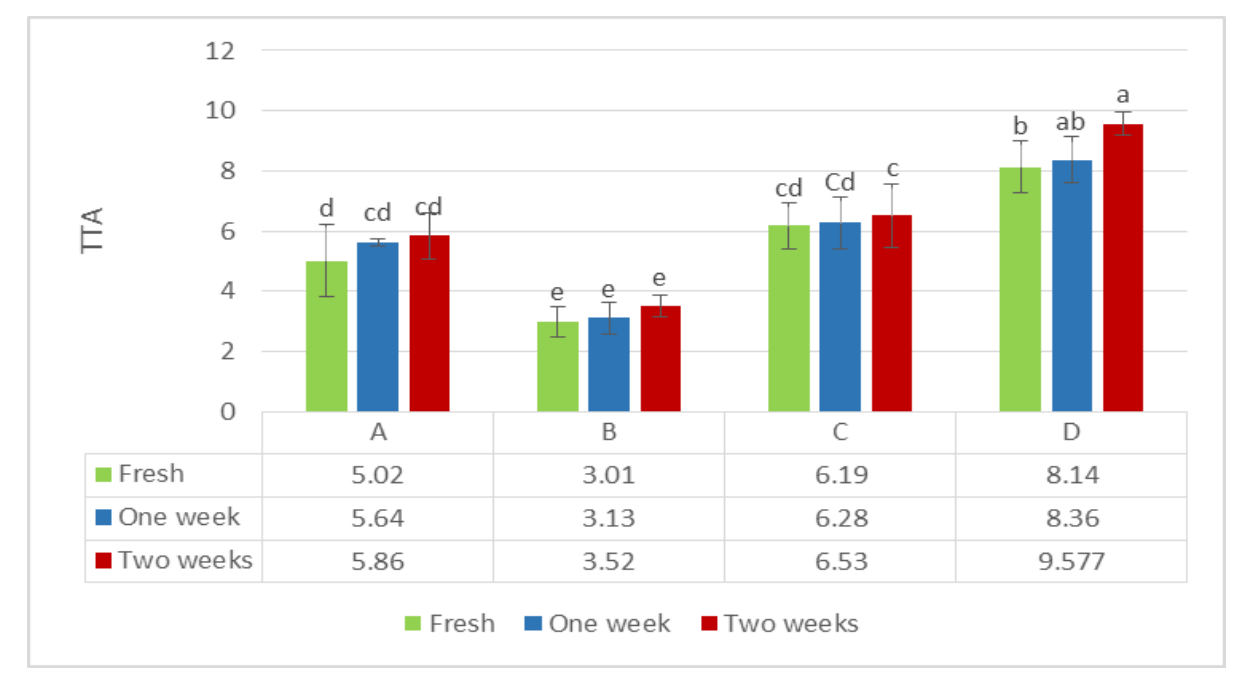

Fig 4. TTA of raisin juices 


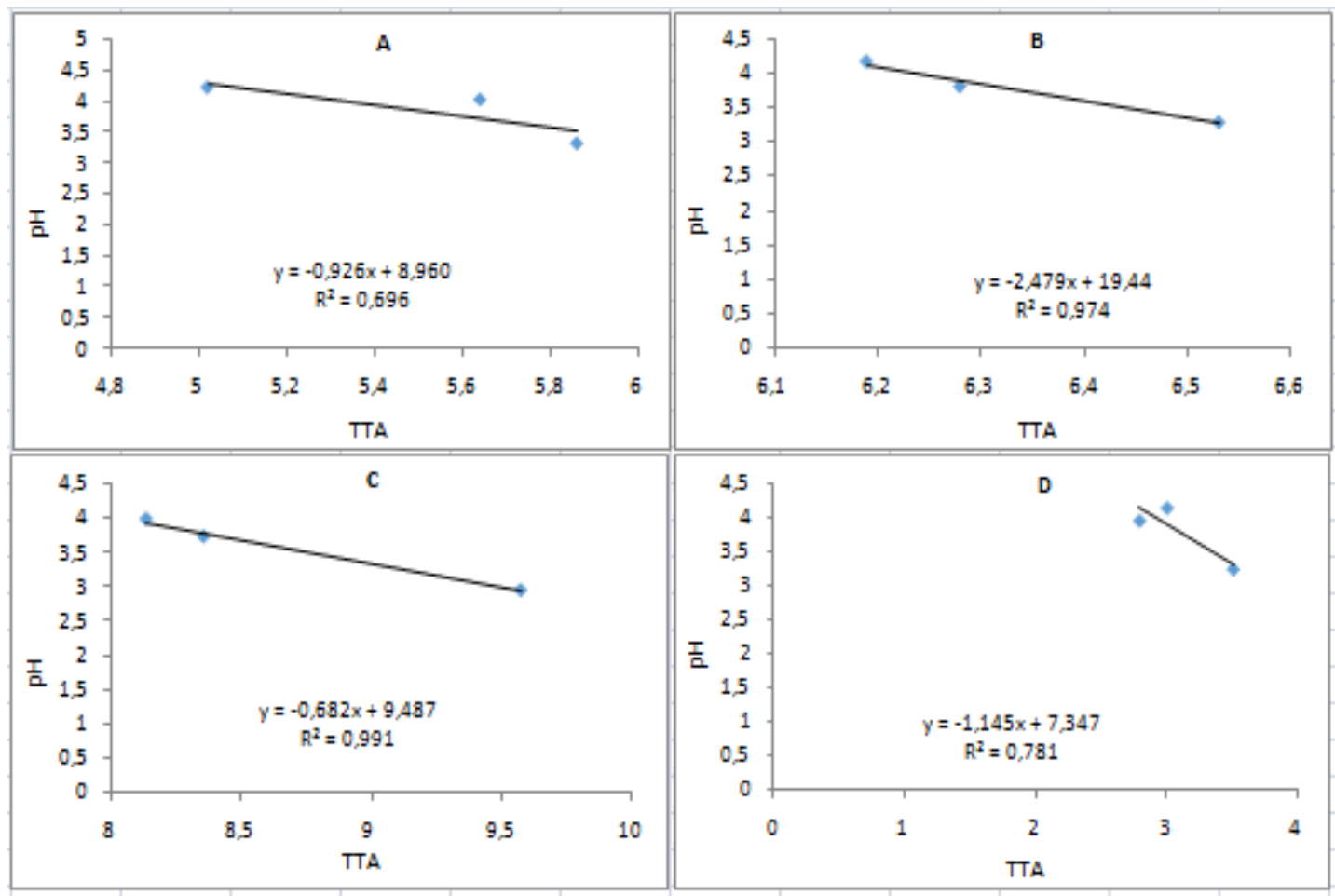

Fig 5. Relationship between $\mathrm{pH}$ and TTA.

In the present study, HPLC method was used to determine the quality and quantity profiles and concentrations of sugars in samples are shown in Table 3. Identified three types of sugars in raisin juice which are included glucose $(53.52-99.127 \mathrm{~g} / \mathrm{L})$ and fructose $(45.04-104.80 \mathrm{~g} / \mathrm{L})$ as well as the trace amount of sucrose (0-16.67 g/L). These results were consistent with the results of Duran (2014) who observed that glucose and fructose concentration of 8 different grape cultivars were the predominant sugars in grape berries ranging from 89.4 to $144.24 \mathrm{~g} / \mathrm{L}$ and from 92.1 to $139.4 \mathrm{~g} / \mathrm{L}$, respectively. According to the table, glucose/fructose ratio was between 0.97-1.07. Furthermore, the ratio of glucose/(fructose + sucrose) was between 0.95-1.06. These are similar to results reported by several researchers. Shiraishi et al.(2010) reported that the ratio of glucose/(fructose + sucrose) is higher than 0.8 depend on types of grapes based on sugar composition. Dai et al (2011) reported that the ratio of glucose to fructose ranged between $0.47-1.12$, depend on the maturity of grapes. On the other hand, Elsheikh, et al (2014), illustrated that, the total sugars of Abu Samaka concentrate stored in the refrigerator decreased after 2 months, these illustrate consistent with the obtained results in the present study.

\subsection{Determination of phenolic compounds by using HPLC}

Refrigeration slows down the chemical and biological processes in foods, and the accompanying deterioration and loss of quality of nutrients. The occurrence of sufficient amount of phytochemical such as carotenoids, flavonoids, and bioactivity of phenolic acid compounds in grape or raisin juice can be standard the quality and high nutrition value. Kahkonen et al., (2012) described that, the grape juice is a major source of bioactive compounds such as phenolic compounds and the consumption of this product is related to several health benefits to consumers. Table 4 summarizes all identification and quantification of phenolic compounds determined in studied raisins (seed and flesh), fresh raisin juice samples and raisin juice refrigerated for 14 days.

In this study, the result showed that chlorogenic acid, gallic, and vanilic acid were detected as a three types of phenolic bioactive compounds in both seeds and flesh of raisins individually. Furthermore, the sum of total phenolic acids quantified in seeds and flesh of raisins varied from 933.57 to $1434.13 \mathrm{mg} / \mathrm{kg}$ and 1060.85 to $2645.59 \mathrm{mg} / \mathrm{kg}$ for samples B, D, A and C, respectively. 
Table 3. Sugar content of black raisin juices

\begin{tabular}{ccccccc}
\hline & & \multicolumn{3}{c}{ Sugar Concentrations (g/L) } & \multicolumn{2}{c}{ Significant Ratios (\%) } \\
\cline { 3 - 7 } Samples & Times & Glucose & Fructose & Sucrose & Glu/Fru & Glu/(Fru+ Suc) \\
\hline A & Fresh & 79.30 & 83.43 & 0 & 0.95 & 0.95 \\
A & One week & 77.69 & 82.85 & 0.26 & 0.93 & 0.93 \\
A & Two weeks & 53.52 & 45.04 & 0.89 & 1.18 & 1.16 \\
B & Fresh & 99.12 & 104.80 & 6.52 & 0.94 & 0.89 \\
B & One week & 94.39 & 100.51 & 0.01 & 0.93 & 0.93 \\
B & Two weeks & 99.10 & 98.71 & 0.46 & 1.00 & 0.99 \\
C & Fresh & 63.15 & 57.90 & 0 & 1.09 & 1.09 \\
C & One week & 62.86 & 60.05 & 0.36 & 1.04 & 1.04 \\
C & Two weeks & 60.05 & 53.26 & 0.04 & 1.12 & 1.12 \\
D & Fresh & 67.37 & 68.85 & 16.67 & 0.97 & 0.78 \\
D & One week & 66.60 & 70.64 & 0.16 & 0.94 & 0.94 \\
D & Two weeks & 56.93 & 53.15 & 0.15 & 1.07 & 1.06 \\
\hline
\end{tabular}

Table 4. Phenolic acids in seed and flesh of raisin

\begin{tabular}{lcccccccc}
\hline & \multicolumn{7}{c}{ Phenolic Acid Concentrations (mg/kg) } \\
\cline { 2 - 9 } Phenolic acids & \multicolumn{2}{c}{ A } & \multicolumn{2}{c}{ B } & \multicolumn{2}{c}{ C } & \multicolumn{1}{c}{ D } \\
\cline { 2 - 9 } & Seed & Flesh & Seed & Flesh & Seed & Flesh & Seed & Flesh \\
\hline Gallic acid & 404.96 & 532.69 & 607.78 & 650.46 & 699.31 & 704.01 & 818.76 & 745.68 \\
Chlorogenic acid & 604.86 & 428.26 & 278.09 & 843.84 & 592.5 & 1855.8 & 599.7 & 1137.34 \\
Vanilic acid & 27.19 & 99.90 & 47.70 & 108.55 & 15.75 & 85.78 & 15.67 & 77.22 \\
Total & 1037.01 & 1060.85 & 933.57 & 1602.85 & 1307.56 & 2645.59 & 1434.13 & 1960.24 \\
\hline
\end{tabular}

The variation of phenolic concentration in seeds and flesh of raisin is caused from the variety of grapes, drying process to produce raisins and storage period, as described by Hassan et al (2015). The results we obtained in this study are in good agreement with the results obtained by Shi et al (2003) and by Eyduran et al (2015). On the other hand, the results given in Table 5 shows that the same phenolic acid compounds identified with a different concentration in fresh raisin juice and in refrigerated raisin juices for one and two weeks. In terms of gallic, chlorogenic and vanilic acids the highest contents were proved with fresh raisin juice samples D, C and A respectively, which were significantly different from the others. This result is indicated the high nutrient value regarding of bioavailability of phenolic compounds. The increase and reduce levels of this compounds as well as create and degrade the organoleptic qualities of raisin juice for each term of phenolic compounds individually, after one and two weeks of storage were observed. The gallic acid compound was significantly increased in sample A after one week and at the end of storage period of raisin juice, while slightly increased in sample $\mathrm{C}$ after both storages as well as sample D was slightly increased after one week and significantly increased after two weeks of storage for the same term of phenolic acids compound (Fig. 6). Hence, the reduce of gallic acid in fresh raisin juice sample B was no significantly difference between one and two weeks of storage. However, the highest increase in the level (17.23) of gallic acid was recorded in sample A after two weeks. In the present study, clorogenic acid was significantly increased in sample A and B after one week storage, 
while the vanilic acid compound was significantly changed in samples A and did not significantly changed in sample B after one and two weeks. At the end of refrigerated

Table 5. Galic, chlorogenic and vanilic acids in raisin juices

\begin{tabular}{lccccl}
\hline & \multicolumn{4}{c}{ Phenolic Acid Concentrations (mg/kg) } & \\
\cline { 2 - 5 } Phenolic acids & $\mathbf{A}$ & $\mathbf{B}$ & $\mathbf{C}$ & $\mathbf{D}$ & Storage \\
\hline Galic acids & $67.99 \pm 0.53$ & $52.09 \pm 0.10$ & $104.37 \pm 0.15$ & $115.63 \pm 0.56$ & \\
Chlorogenic acid & $67.96 \pm 0.67$ & $29.48 \pm 0.44$ & $242.87 \pm 0.85$ & $132.66 \pm 0.20$ & Fresh \\
Vanilic acid & $17.67 \pm 0.42$ & $6.61 \pm 0.01$ & $13.68 \pm 0.65$ & $8.43 \pm 0.02$ & \\
Total & 153.62 & 88.18 & 360.91 & 256.71 & \\
\hline Galic acids & $81.38 \pm 0.09$ & $50.86 \pm 0.74$ & $106.07 \pm 0.37$ & $118.28 \pm 0.47$ & \\
Chlorogenic acid & $84.28 \pm 0.23$ & $33.66 \pm 0.29$ & $232.98 \pm 0.05$ & $70.37 \pm 1.65$ & One week \\
Vanilic acid & $12.72 \pm 0.02$ & $6.68 \pm 0.10$ & $12.75 \pm 0.15$ & $7.95 \pm 0.17$ & \\
Total & 178.38 & 91.19 & 351.80 & 196.60 & \\
\hline Galic acids & $85.22 \pm 0.28$ & $47.48 \pm 0.81$ & $110.03 \pm 0.20$ & $126.03 \pm 0.09$ & \\
Chlorogenic acid & $79.30 \pm 0.37$ & $26.99 \pm 028$ & $232.49 \pm 0.01$ & $42.62 \pm 0.18$ & \multirow{2}{*}{ Two weeks } \\
Vanilic acid & $12.99 \pm 0.05$ & $6.32 \pm 0.02$ & $13.34 \pm 0.35$ & $8.31 \pm 0.27$ & \\
Total & 177.51 & 80.79 & 355.86 & 176.96 & \\
\hline
\end{tabular}

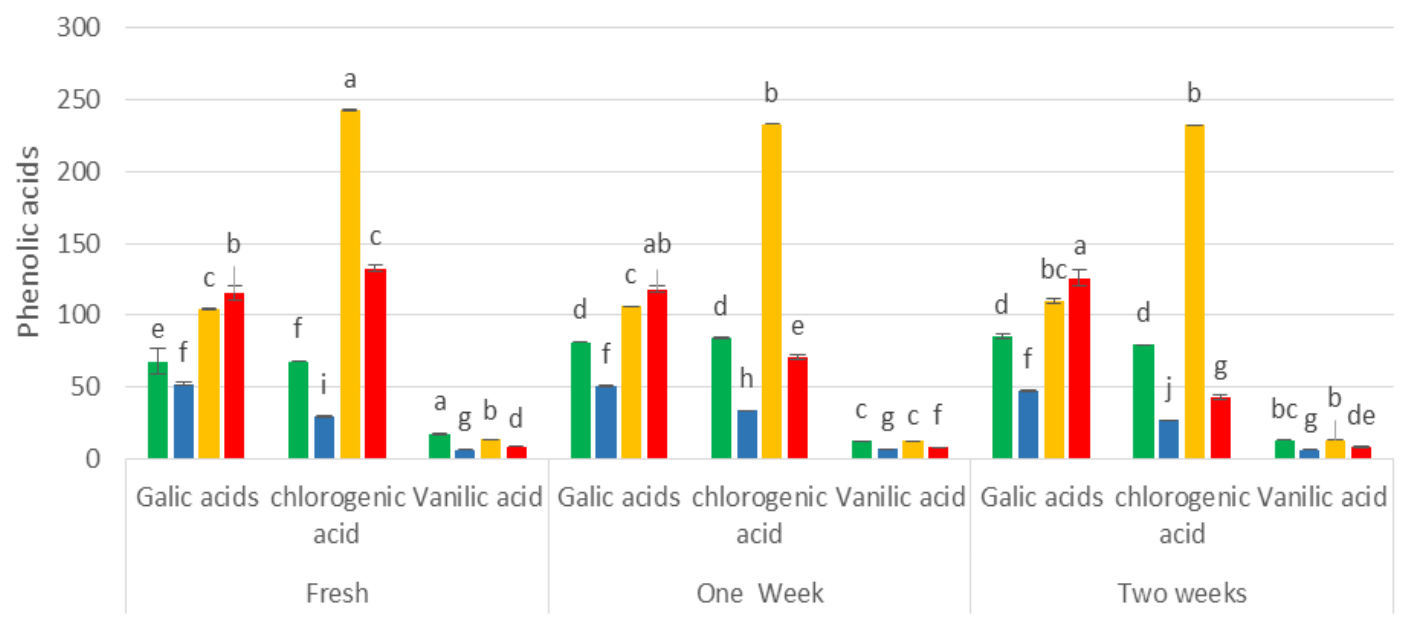

$\square \mathrm{A} \square \mathrm{B} \square \mathrm{D}$

Fig 6. Phenolic acids in raisin juice.

storage period, the variations in the availability of phenolic compounds might be referring to the fermentation and some chemical reaction and enzyme activity as well as the type of grapes used for production of raisins and juices may greatly influence its phenolic composition (Eyduran, et al 2015). 


\subsection{Assay of PPO activity}

One of the main obstacles of undesired of quality of fruit juice results from enzymatic browning, which is caused by the act of polyphenol oxidase enzyme. The freshness of fruit juices can be prolonged for a few days by storing in a refrigerator. Thus, the microbial contamination that reduce the quality, distording the sensorial evaluation and causes turbidity, browning and sedimenting during storage can be prevented (Lea, 1994). Yemenicioğlu and Cemeroglu (1997) had illustrated that the oxidative enzymes such as polyphenol oxidase and peroxidase are the main factor in reducing the nutritional and sensorial values as well as color and flavor of fresh fruit juice. As shown in Fig. 7, the highest value of polyphenoloxidase enzyme was observed in raw raisin sample D, and it was superior to other samples. The lowest level of PPO was found in sample A. Furthermore, under the current experimental conditions, among fresh raisin juice samples, the maximum value of PPO was found in fresh raisin juice sample A and the minimum value was observed in sample D (Fig. 8). Perhaps the variation in the results is due to the species of the grapes, the acidity, the storage time, the type of drying and juice treatment process. These results are consistent with results obtained in previous studies (Wesche-Ebeling and Montgomery, 1990; Zemel et al., 1990).

\subsection{Water activity}

Water activity $\left(\mathrm{a}_{\mathrm{w}}\right)$ indicates how tightly water is bound, structurally or chemically, in food products. he predicts food safety and stability with respect to microbial growth, chemical/biochemical reaction rates, and physical properties are combined the concept of aw which has been an essential role for food safety. To attempt to preserve the quality and safety or the chemical stability (Non- enzymatic browning reaction) of foods and activation of microorganisms, it's possible by controlling the water activity content in food products. Therefore, the non-enzymatic browning reaction increases with increasing as well as this reaction will reach to the maximum reaction when the range of reaching 0.6 to 0.7 . The lowest $a_{w}$ at which the vast majority of food spoilage bacteria will grow is about 0.90 . The $\mathrm{a}_{\mathrm{w}}$ of molds

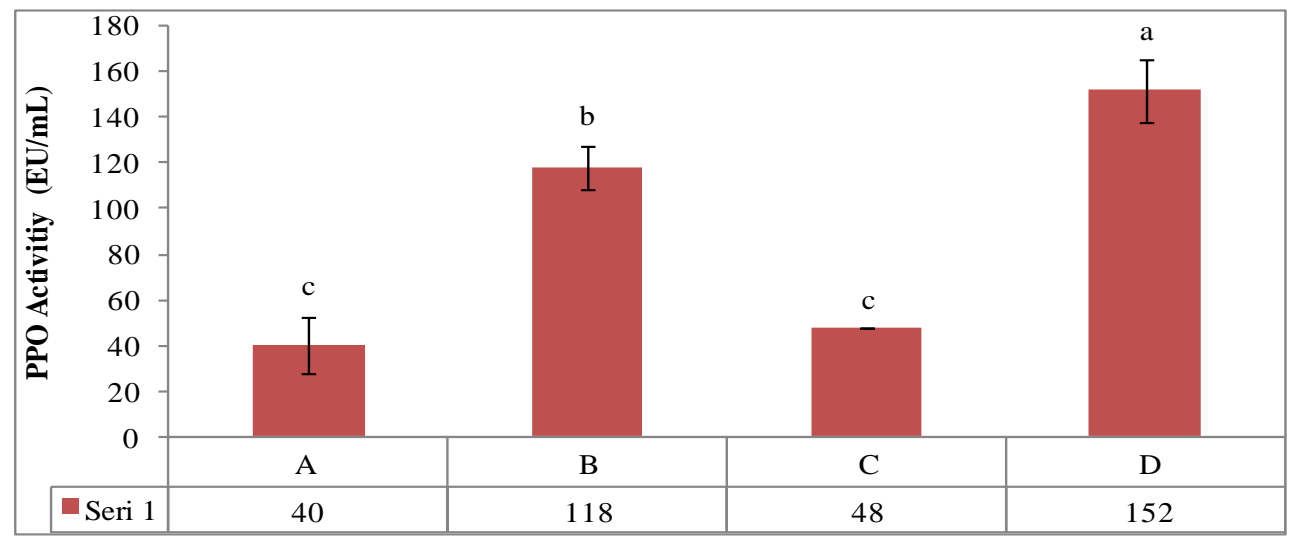

Fig 7. PPO activities in raisins 


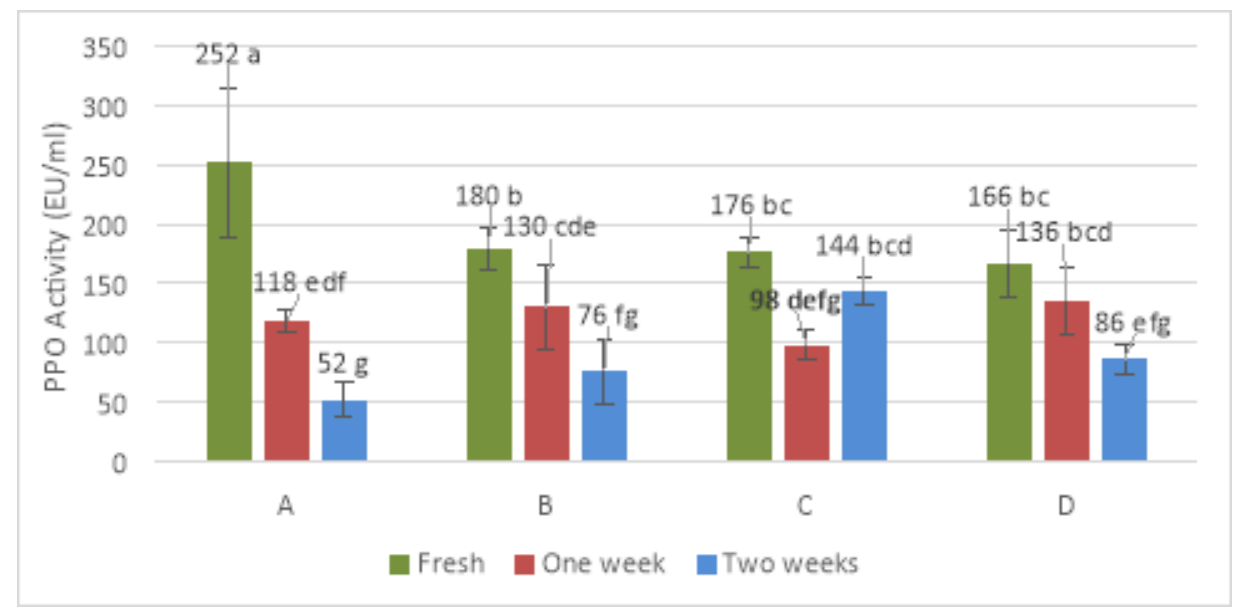

Fig 8. PPO activities in raisin juices

and yeasts growth are about 0.61 with the lower limit for growth of mycotoxigenic molds at $0.78 \mathrm{a}_{\mathrm{w}}$ (Beuchat 1981). The $a_{w}$ of pure water is 1.00 and the aw of a completely dehydrated food is 0.00 . The $a_{w}$ of a food on this scale from $0.00-1.00$ is related to the equilibrium relative humidity of the food on a scale of $0-100 \%$. Thus, \% Equilibrium Relative Humidity $(E R H)=a_{w} \times 100$. The $a_{w}$ of a food describes the degree to which water is "bound" in the food, its availability to participate in chemical/biochemical reactions, and its availability to facilitate the growth of microorganisms (Mossel and others 1995). The results for the characterization of the raisins and fresh raisin juices as well as raisin juices refrigerated for two weeks are represented in Fig. 9 and Fig. 10, respectively. The contribution to the of raisins and fresh raisins ranged from $0.484-0.519$ and $0.949-0.955$, respectively in $25^{\circ} \mathrm{C}$. The results of $\mathrm{a}_{\mathrm{w}}$ in raisins were lower than those found by Mossel et al. (1996), the approximate $\mathrm{a}_{\mathrm{w}}$ levels in dried fruits between 0.55-0.80. The difference might be due to the drying process, and juice processing. Furthermore, the $a_{w}$ of the most of raisin juice products slightly increases with increasing the shelf life of product for one week and at the end of refrigerated storage period. This phenomenon is due to decease of total soluble solid.

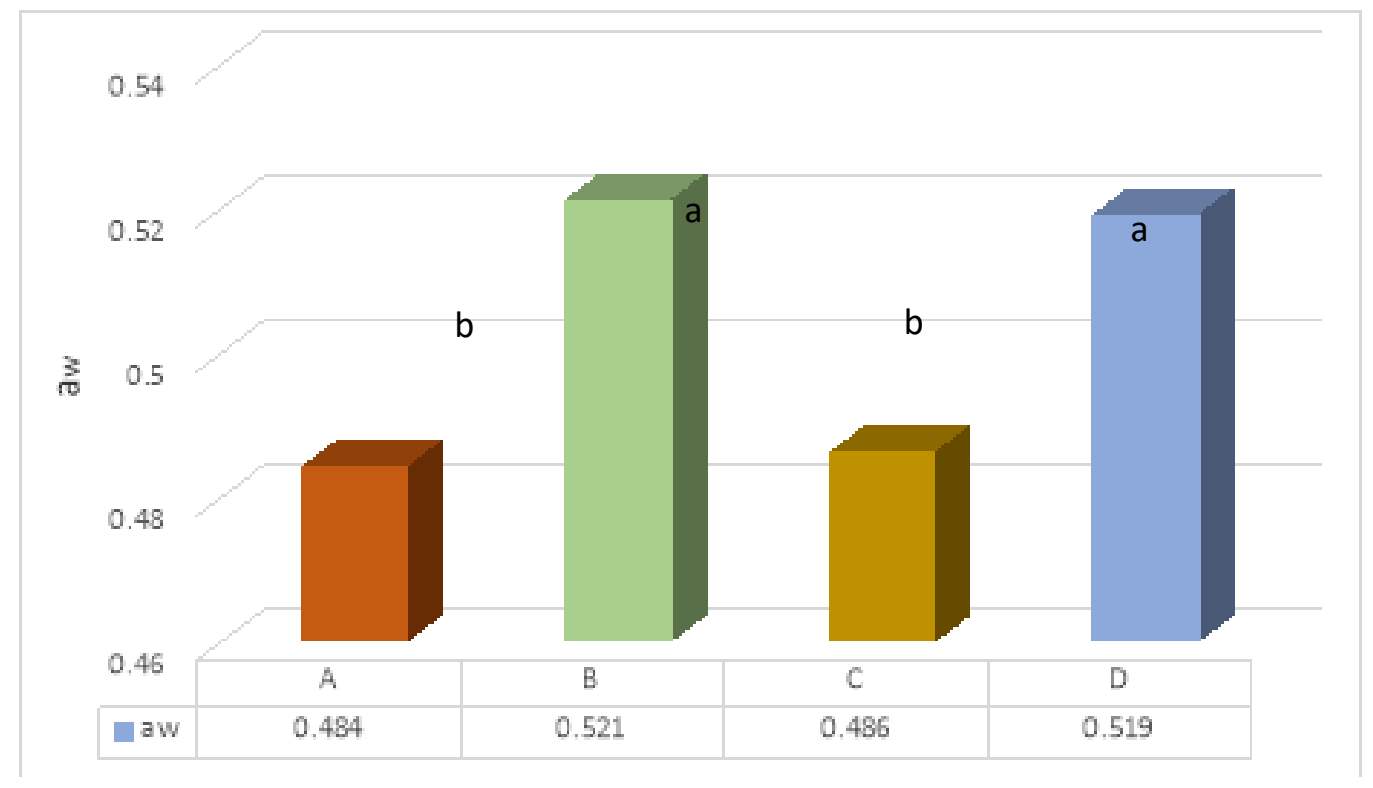

Fig 9. Water activities in raisins 


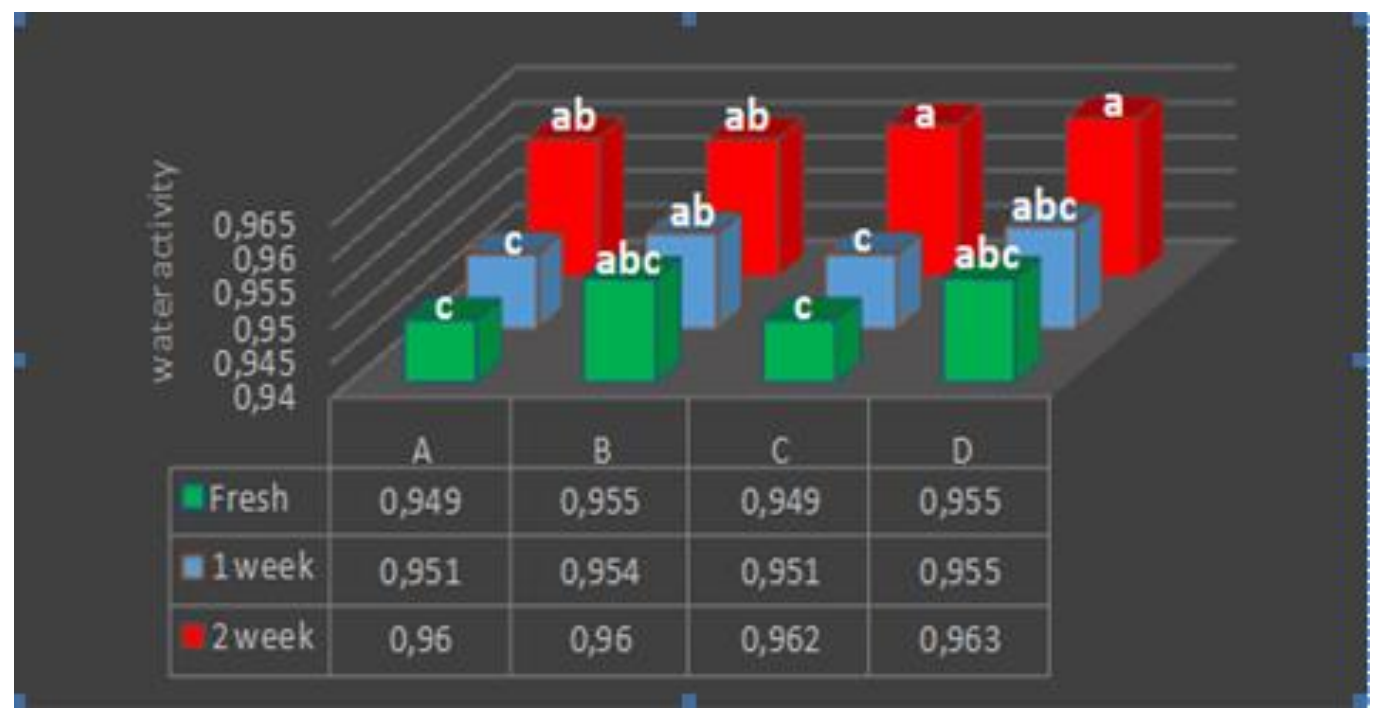

Fig 10. Water activities in raisin juice.

\subsection{Total bacterial counts}

Ensuring food safety, adequate nutrition content and bioavailability free from preservatives and additives are the curiosities of public health and consumer protection, which have been processed in a fashion to minimize the influence on the original food products (Reed and Grivetti, 2000). Enhancing consumer's health due to inhibition of diseases, it is important the performance of hygienic condition during raisin juice production. Good manufacturing practice (GMP) has influenced the quality and safety of raisin juice. Raisin juice will be contaminated at any points from raw material to end of the production and could be the source of infectious pathogens till to reach the consumers. The microbial population depends on several factors such as $\mathrm{pH}, \mathrm{a}_{\mathrm{w}}$ true hygienic condition, treatments, and storage condition. The refrigerator is not always the best way to extend the shelf life with retention of the nutrient value of fruit juice.

It can be seen in the histogram that the increase in the number of micro-organisms was during the first week of refrigeration in most samples, then it accelerated at the end of storage period, as well as the results showed the maximum and minimum initial of total count microorganisms in fresh raisin juice were 8.48 and $7.09 \mathrm{CFU} / \mathrm{ml}$, in samples D and B, respectively (Fig. 11). The reason for this result might be due to the degree of achieving hygienic condition during raisin juice processing. Furthermore, there were no significant difference in the population of microorganisms in all fresh samples compares the samples at the middle and the end of storage period in refrigerator or the survival of microorganisms in fresh raisin juice was slightly increased after one and two weeks of storage in refrigerator and these results are in accordance with a previous study done by Elsheikh et al (2014) that investigated the total viable count was nil at zero time of storage and started to increase after 2 months. On teh other hand, this results agrees with results obtained by Kaddumukasa (2017) in the microbiological analyses of passion fruit, pineapple, and mango juices in dark and light bottles at $24^{\circ} \mathrm{C}$ and $4{ }^{\circ} \mathrm{C}$ were conducted in Kampala, Uganda for 12 days for juices.

\subsection{Sensorial evaluation}

In this study, sensorial evaluation is used as an essential part of quality control as well as quality assurance of fresh raisin juice and samples refrigerated for two weeks. Sensory analysis was performed with 10 panelists ( 5 females and 5 males and between 18 and 40 years of age), on first week, second week and third week of storage in terms of consumer acceptability. The evaluated attributes were the intensity of sensory properties was included (appearance, aroma, taste, sweetness and texture mouth feel). Panelists scored the samples using a five-point hedonic scale where a score of 1 extremely dislike and a score of 5 extremely like.

Table 6 shows that the fresh raisin juice samples showed the highest acceptability in all the sensory attributes. This may be related to the freshness of the juice (Akusu, et al., 2016). Further, there was significantly decrease in all sensory characteristics of fresh raisin juice compared to other samples at the 
end of storage period under the refrigerated condition, as illustrated in Table 6. This result opposite the work of Adebayo Tayo and Akpeji (2016), who reported that there was no significant difference in taste, aroma, color, and appearance of the probioticated juice samples during 4 weeks storage.

Otherwise, the appearance evaluation of the fresh raisin juice for all samples compared with the samples stored for 1 week exhibited similar trends as well as significantly decrease of flavor, taste and sweetness characteristics in all fresh raisin juice samples compared their counterparts stored for 1 week, except samples B and A. This result agree with study of Akusu et al (2016) who found that sensory evaluation result showed a significant difference in the attributes of colour, flavour, taste and overall acceptability of the orange/pineapple juice blends compared to the reference sample.

Although, the results showed that the texture mouth feel in samples A and $\mathrm{C}$ was changed significantly after 1 week, in contrast, a comparison results of the texture mouthfeel of fresh raisin juice in samples $\mathrm{B}$ and $\mathrm{D}$ to the first storage study were no significant. Furthermore, these results showed significant differences between all fresh raisin juice samples and refrigerated for 14 days, except sample A. Similar results reported by Bhardwaj and Nandal (2014). Their results indicated that flavour, colour and bitterness score of juice blends, decreased with advancement of storage period.

The reasons for the changed the sensory evaluation, might be referring to some chemical, microbial, and enzymatic reactions as described by same authers and the juice blend can be kept conveniently for three weeks without preservatives, in contrast to the results reported by Islam et al (2015).

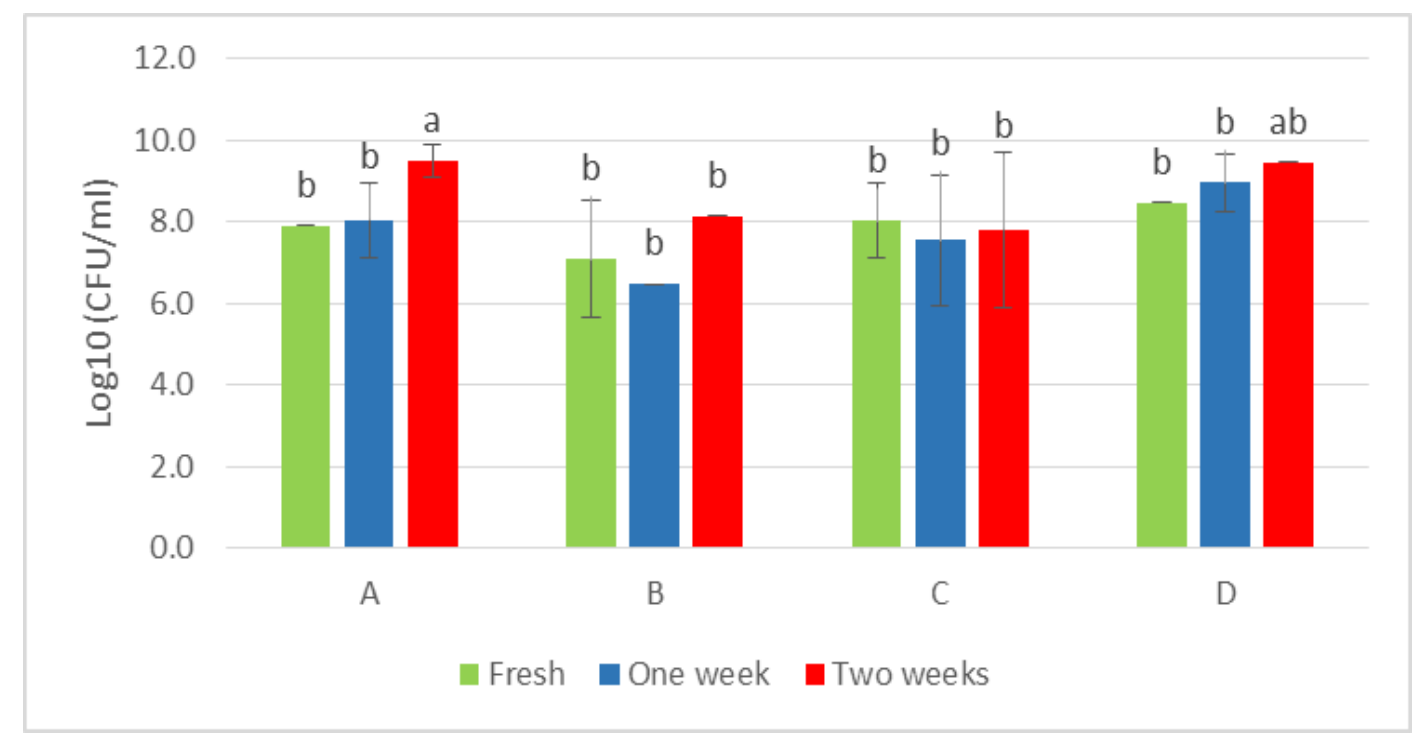

Fig 11. Total bacterial counts 
Table 6. Sensorial evaluation of raisin juices

\begin{tabular}{lccccc}
\hline Test Time & Color & Flavor & Taste & Sweetness & Texture / Mouthfeel \\
\hline A Fresh & $4 \pm 0.62 \mathrm{ab}$ & $4.35 \pm 0.52 \mathrm{a}$ & $3.75 \pm 0.67 \mathrm{a}$ & $3.40 \pm 0.80 \mathrm{a}$ & $3.75 \pm 1.06 \mathrm{a}$ \\
B Fresh & $3.60 \pm 0.73 \mathrm{abc}$ & $3.75 \pm 0.67 \mathrm{abc}$ & $3.40 \pm 3.93 \mathrm{a}$ & $3.05 \pm 1.25 \mathrm{a}$ & $3.30 \pm 0.67 \mathrm{ab}$ \\
C Fresh & $3.80 \pm 0.88 \mathrm{ab}$ & $3.80 \pm 1.22 \mathrm{ab}$ & $3.75 \pm 0.35 \mathrm{a}$ & $3.35 \pm 0.81 \mathrm{a}$ & $3.80 \pm 0.97 \mathrm{a}$ \\
D Fresh & $4.25 \pm 0.75 \mathrm{a}$ & $3.85 \pm 1.10 \mathrm{ab}$ & $3.65 \pm 0.78 \mathrm{a}$ & $3.50 \pm 0.91 \mathrm{a}$ & $3.20 \pm 1.25 \mathrm{ab}$ \\
\hline A One week & $3.35 \pm 0.78 \mathrm{bcd}$ & $2.60 \pm 0.73 \mathrm{de}$ & $2.35 \pm 0.85 \mathrm{~b}$ & $1.95 \pm 0.76 \mathrm{~cd}$ & $2.5 \pm 1.08 \mathrm{~b}$ \\
B One week & $3.85 \pm 0.62 \mathrm{ab}$ & $3.10 \pm 1.24 \mathrm{bcd}$ & $3.25 \pm 0.97 \mathrm{a}$ & $2.90 \pm 0.80 \mathrm{ab}$ & $2.75 \pm 1.07 \mathrm{~b}$ \\
C Oneweek & $3.55 \pm 0.59 \mathrm{abc}$ & $2.35 \pm 0.57 \mathrm{def}$ & $2 \pm 0.33 \mathrm{bc}$ & $2 \pm 0.62 \mathrm{~cd}$ & $2.50 \pm 0.81 \mathrm{~b}$ \\
D One week & $4.05 \pm 0.49 \mathrm{ab}$ & $3 \pm 0.52 \mathrm{~cd}$ & $2.20 \pm 0.71 \mathrm{~b}$ & $2.30 \pm 0.91 \mathrm{bc}$ & $2.50 \pm 0.57 \mathrm{~b}$ \\
\hline A Two weeks & $3.1 \pm 0.61 \mathrm{~cd}$ & $1.5 \pm 0.52 \mathrm{gh}$ & $1.30 \pm 0.34 \mathrm{ed}$ & $1.35 \pm 0.52 \mathrm{de}$ & $1.25 \pm 0.58 \mathrm{c}$ \\
B Two weeks & $2.80 \pm 0.53 \mathrm{~d}$ & $1.80 \pm 0.67 \mathrm{fhg}$ & $1.25 \pm 0.63 \mathrm{ed}$ & $1.15 \pm 0.78 \mathrm{e}$ & $1.55 \pm 0.55 \mathrm{c}$ \\
C Two weeks & $2.70 \pm .58 \mathrm{~d}$ & $1.25 \pm 0.58 \mathrm{~h}$ & $0.70 \pm 0.53 \mathrm{e}$ & $1.10 \pm 0.51 \mathrm{e}$ & $1.35 \pm 0.57 \mathrm{c}$ \\
D Two weeks & $3.90 \pm 0.80 \mathrm{ab}$ & $2.20 \pm 0.75 \mathrm{efg}$ & $1.50 \pm 0.47 \mathrm{~cd}$ & $1.40 \pm 0.56 \mathrm{ed}$ & $1.50 \pm 0.57 \mathrm{c}$ \\
\hline
\end{tabular}

\section{Conclusions}

In this study, the differences in terms of both quality and safety of the samples were given. As a result it can be said that the fresh raisin juice samples were superior than the stored samples in refrigerator during 1-2 weeks based on quality parameters such as total soluble solids, $\mathrm{pH}$, the quantity of phenolic acids, sensory evaluation, appearance, sweetness and aroma.

Furthermore, in this research three types of sugars which include glucose, fructose, and sucrose as well as three types of essential bioactive phenolic acid compounds which involves gallic, chlorogenic and vanilic acids with different concentrations have been identified.

Consequently, it can be said the variation of phenolic concentration in seeds and flesh of raisin is caused from the variety of grapes, drying process to produce raisins and storage period. Furthermore, the evaluation of bacterial count and water activity showed that the safety of untreated raisin juice samples depends on the good hygienic practices (GMP) and storage condition until to reach the consumers.

\section{Acknowledgement}

The authors acknowledge to Scientific Research Projects Coordinatorship of Siirt University for their financial support.

\section{References}

Abdullah, S.A. (2012). Alternative processing techniques for pasteurization of liquid foods:Microwave, ohmic heating and ultraviolet light, Doctoral dissertation, University of Hawai'i at Manoa, Manoa 1-143.

Adebayo, Tayo, B., Akpeji, S. 2016. Probiotic viability, physicochemical and sensory properties of probiotic pineapple juice. Ferment. 2(4): 20-31.

Aktas, T., Polat, R. (2007). Changes in the drying characteristics and water activity values of selected pistachio cultivars during hot air drying. J. Food Process. Eng. 30(5): 607-624.

Akusu, O.M., Kiin-Kabari, D.B., Ebere, C.O. (2016). Quality characteristics of orange/pineapple fruit juice blends. Am. J. Food Sci. Technol. 4(2): 43-47.

Amerine, M.A., Ough, C.S. (1981). Methods for Analysis of Musts and Wines. J. Inst. Brew. 87(4): 223-224. 
Arin, S., Akdemir, S. (2004). Quality properties changing of grape during storage period. $J$. Biol.Sci. 4(2): 253-257.

Awuah, G.B., Ramaswamy, H.S., Economides, A. (2007). Thermal processing and quality: principles and overview. Chem. Eng. Process. 46(6): 584-602.

Beuchat, L.R. (1981). Microbial stability as affected by water activity. Cereal Foods World. 26(7): 345-349.

Bhardwaj, R.L., Nandal, U., (2014). Effect of storage temperature on physico-chemical and sensory evaluation of kinnow mandarin juice blends. J. Food Process. Technol. 5(8):1-4.

Bhardwaj, R.L., Pandey, S. (2011). Juice blends - a way of utilization of under-utilized fruits, vegetables, and spices: a review. Crit. Rev. in Food Sci. Nutr. 51(6): 563-570.

Boulton, R. (1980). The general relationship between potassium, sodium and $\mathrm{pH}$ in grape juice and wine. Am. J. Enol. Vitic. 31(2): 182-186.

Braide, W., Oranusi, S.U., Otali, C.C. (2012). Microbiological status of processed fruit juice sold in the commercial city of Onitsha. Scholarly J. Biol. Sci. 1(3): 25-30.

Bub, A., Watzl, B., Blockhaus, M., Briviba, K., Liegibel, U., Müller, H., Pool-Zobel, B.L., Rechkemmer, G. (2003). Fruit juice consumption modulates antioxidative status, immune status and DNA damage. J. Nutr. Biochem. 14(2): 90-98.

Bull, M.K., Zerdin, K., Howe, E., Goicoechea, D., Paramanandhan, P., Stockman, R., Sellahewa, J., Szabo, E.A., Johnson, R.L., Stewart, C.M. (2004). The effect of high pressure processing on the microbial, physical and chemical properties of Valencia and Navel orange juice. Innov. Food Sci. Emerg. Technol. 5: 135-149.

Chitarra, M.I.F., Chitarra, A.B. (2005). Post-Harvest Fruits and Vegetables: Physiology and Handling. 2nd ed., UFLA: Lavras, Brazil, p. 785.

Christensen, L.P., Bianchi, M.L., Lynn, C.D., Kasimatis, A.N., Miller, M.W. (1995). The effects of harvest date on Thompson seedless grapes and raisins. I. Fruit composition, characteristics, and yield. Am. J. Enol. Vitic. 46(1): 10-16.

Dai, Z.W., Ollat, N., Gomès, E., Decroocq, S., Tandonnet, J.P., Bordenave, L., Pieri, P., Hilbert, G., Kappel, C., van Leeuwen, C., Vivin, P. (2011). Ecophysiological, genetic, and molecular causes of variation in grape berry weight and composition: a review. Am. J. Enol. Vitic. 62(4): 413-425.

Dawson, C.R., and Magee, R.J. (1955). Plant tyrosinase (polyphenol oxidase). Methods Enzymol.2: $817-821$

Dharmadhikari, M. (2010). Composition of grapes. Iowa StateUniversity, Iowa State University Extension:

Ames, Iowa. (https://www.extension.iastate.edu/wine/files/page/files/compositionofgrapes.pdf) (February 12, 2019)

Duran, Z. (2014). Malatya ve Elaziğ illerinde yetiştirilen bazi üzüm çeşitlerinin organik asit, şeker ve fenolik madde bileşikleri ile antioksidan aktivitelerinin belirlenmesi. M.Sc. Thesis, İnönü University, 1-62. 
Elsheikh, A.O., Nour, A.E.A., Elkhalifa, A.E.O. (2014). Effect of storage on the quality attributes of concentrates of two mango (Mangifera indica) varieties grown in Sudan. Br. J. Appl. Sci. Technol. 4(14): 2069-2078.

Eyduran, S.P., Akin, M., Ercisli, S., Eyduran, E., Maghradze, D. (2015). Sugars, organic $\quad$ acids, and phenolic compounds of ancient grape cultivars (Vitis vinifera L.) from Igdir province of Eastern Turkey. Biol. Res. 48(2): 2-8.

Gardner, P.T., White, T.A., McPhail, D.B., Duthie, G.G. (2000). The relative contributions of vitamin C, carotenoids and phenolics to the antioxidant potential of fruit juices. Food Chem. 68(4): 471474.

Gauillard, F., Richard-Forget, F. (1997). Polyphenoloxidases from Williams pear (Pyrus communis L, cv Williams): activation, purification and some properties. J. Sci. Food Agric. 74(1), 49-56.

Hassan, N.A., El-Halwagi, A.A., Sayed, H.A. (2012). Photochemical, antioxidant and chemical properties accession growth in Egypt. World Appl. Sci. J. 16(8): 1065-1073.

Ibrahim, M.A. (2016). Effect of different storage condition on $\mathrm{pH}$ and vitamin $\mathrm{C}$ content in some selected fruit juices (pineapple, pawpaw and watermelon). Int. J. Biochem. Res. Rev. 2: 1-5.

Iraqi standard. (1988). Grape juices preserved exclusively by physical means. 1207, pp 1.

Kaddumukasa, P.P., Imathiu, S.M., Mathara, J.M., Nakavuma, J.L. (2017). Influence of physicochemical parameters on storage stability: Microbiological quality of fresh unpasteurized fruit juices. Food Sci. Nutr. 5(6): 1098-1105.

Kähkönen, M., Kylli, P., Ollilainen, V., Salminen, J.P. and Heinonen, M. (2012). Antioxidant activity of isolated ellagitannins from red raspberries and cloudberries. J. Agric. Food Chem. 60(5): 11671174 .

Kanellis, A.K. and Roubelakis-Angelakis, K.A. (1993). Grape. In: Seymour, G.B., Taylor J.E., Tucker G.A. (Eds.). Biochemistry of fruit ripening. Chapman and Hall, London, 189-234.

Kliewer, W.M. (1966). Sugars and organic acids of Vitis vinifera. Plant physiol. 41(6): 923-931.

Lea A.G.H. (1994). Apple juice. In: J. Fry, G. G. Martin, M. Lees (auth.), P. R. Ashurst (Eds.). Production and Packaging of Non-Carbonated Fruit Juices and Fruit Beverages. Chapman \& Hall. Glasgow. 153-196

Marumo, K., Waite, J.H. (1986). Optimization of hydroxylation of tyrosine and tyrosine-containing peptides by mushroom tyrosinase. Biochim. Biophys. Acta. 872 (1-2): 98-103.

Mehmood, Z., Zeb, A., Ayub, M., Bibi, N., Badshah, A., Ihsanullah, I. (2008). Effect of pasteurization and chemical preservatives on the quality and shelf stability of apple juice. Am. J. Food Sci. Technol. 3(2): 147-153.

Mgaya-Kilima B., Remberg, S.F., Chove, B.E., Wicklun T. (2014). Influence of storage temperature and time on the physicochemical and bioactive properties of Roselle-fruit juice blends in plastic bottle. Food Sci. Nutr. 2(2): 181-191.

Mossel, D.A.A., Corry, J.E., Struijk, C.B., Baird, R.M. (1996). Essentials of the microbiology of foods: a textbook for advanced studies. John Wiley \& Sons. New Jersey, 1-736

Mullins, M.G., Bouquet, A., Williams, L.E. (1992). Biology of the grapevine. Cambridge University Press. Cambridge, 17-36. 
Reed, B.A., Grivetti, L.E. (2000). Controlling on-farm inventories of bulk-tank raw milk-An opportunity to protect public health. J. Dairy Sci. 83(12): 2988-2991.

Riahi, E., Ramaswamy, H.S. (2004). High pressure inactivation kinetics of amylase in apple juice. $J$. Food Eng. 64(2): 151-160.

SAS. (1999). SAS/STAT User's Guide. Version 8, first edition, SAS Publishing. Cary. 1-2552.

Shi, J., Yu, J., Pohorly, J.E., Kakuda, Y. (2003). Polyphenolics in grape seeds-biochemistry and functionality. J. Med. Food. 6(4): 291-299.

Shiraishi, M., Fujishima, H., Chijiwa, H. (2010). Evaluation of table grape genetic resources for sugar, organic acid, and amino acid composition of berries. Euphytica. 174(1): 1-13.

Tasnim, F., Hossain, M.A., Nusrath, S., Hossain, M.K., Lopa, D., Haque, K.M. (2010). Quality assessment of industrially processed fruit juices available in Dhaka city, Bangladesh. Malays. $J$. Nutr. 16(3): 431-438.

Watts, B.M., Ylimaki, G.L., Jeffery, L.E. and Elias, L.G. (1989). Basic sensory methods for food evaluation. IDRC, Ottawa, 1-164.

Wesche-Ebeling P., Montgomery M.W. (1990). Strawberry polyphenoloxidase: Extraction and partial characterization. J. Food Sci. 55(5): 1320-1324.

Wisal, S., Ullah, J., Zeb, A., Khan, M.Z. (2013). Effect of refrigeration temperature, sugar concentrations and different chemicals preservatives on the storage stability of strawberry juice. Int. J. Eng. Technol. 13(02): 160-168.

$\mathrm{Xu}, \mathrm{K}$., Aide Wang, A., Brown, S. (2012). Genetic characterization of the Malocus with $\mathrm{pH}$ and titratable acidity in apple. Mol. Breed. 30(2): 899-912.

Yemenicioğlu, A., Özkan, M. And Cemeroğlu, B. (1997). Heat inactivation kinetics of apple polyphenoloxidase and activation of its latent form. J. Food Sci. 62(3): 508-510.

Zemel, G.P., Sims, C.A., Marshall, M.R., Balaban, M. (1990). Low pH inactivation of polyphenoloxidase in apple juice. J. Food Sci. 55(2): 562-563. 